\title{
Study On A Decentralization Policy In Indonesia: A Case Study On The Implementation Of Integrated Administrative Service On District Level Of Medan City
}

\author{
Muhammad Arifin Nasution, Muryanto Amin, and Hatta Ridho
}

Faculty of Political Studies of University of Sumatera Utara, Medan

muhammadarifinnasution@gmail.com

\begin{abstract}
In order to accomplish effective public services and able to deliver direct services to the community, in 2010 the Government of Indonesia (GoI) has released released a Ministry Home Affairs Regulation No 4 Year 2010 on manual of Integrated Administrative Service on District Area (in Bahasa shortened into PATEN). To accelerate and to optimize the implementation of this regulation, several regulations have been also released. In the present study, the implementation of PATEN is analyzed by using Medan city, the third biggest city in Indonesia, as the case study. The results show PATEN is not implemented yet, by the government of Medan city. The governments should implement the delegation of authority to the districts so they can activate the PATEN programs as suggested in the ministry regulation. It is suggested that the Medan government carry out the intense socialization of licenses and approaching all level of the community. In particular this can avoid the corruption in license issuing. The government of Medan city need to improve the capacity building of the human resources in order to implement the good and sustainable PATEN.
\end{abstract}

Keywords: decentralization, Indonesia, district, PATEN

\section{INTRODUCTION}

In a government system, decentralization is the spread of power away from the central to local government. It is aimed to empower a local government to gain and explore its local potencies in order to reach an efficient and effective public services (Rohdewohld, 1995). Here, the local government will receive its autonomy. Through an autonomy, an efficient and effective public services can be built, thus a community can easily access their needs for service. In the pasts several decades, the decentralization includes devolution of fiscal, political, and administrative powers and responsibilities from centralized governments to local ones, has spread rapidly through Asian countries (Chattopadhyay, 2012; Cheem and Rondinelli, 2007; Clark et al, 2008, Faguet, 2014; Rumbach, 2016).

Study on the effects and the impacts of decentralization in Asia have been come under scrutiny. Chattopadhyay, 2012 reports a study on the decentralized urban governance participation and accountability in West Bengal's municipalities. The study finds that a large gap exists between the rhetoric surroundings the constitutional provisions of decentralization and their actual implementations. Miller and Bunnell (2013) introduce a problematizing the interplay between decentralized governance and the urban in Asia. Decentralization policies in urbanizing Asia have aimed to encourage the active involvement of urban residents in addressing shared dilemmas concerning issues such as environmental sustainability, public service delivery, community building and socio-political stability in often densely concentrated and ethnically diverse populations. At the same time, however, decentralization within the contexts of globalization and privatization may circumvent critical aspects of democratic procedure if sub-national government officials use their increased access to state power and resources to nurture clientelistic networks of patronage and/or to tap into wider circles of regional or global economic activity at the expense of local urban development. Cain (2014) carry out a research to study the problem and to find out the best practice in the implementation of decentralization to local government in Thailand. In the study 
Kalasin province in Thailand is used as the location of the case study. The results show that the proper implementation of decentralization gives beneficially to development system in local government department.

Indonesia is a particularly interesting case for studying the phenomenon of excessive administrative spending at the local level (Sjahrir et al, 2016). This because Indonesia is the fourth biggest country in the world (the third largest democracy and the second largest in the developing world) also it is a young democracy with a history of weak institutions and high levels of corruption, including a corrupt civil service (McLeod, 2005). The most important, Indonesia has experienced on a dual reforms democratization and decentralization in the same time, both rapid and fundamental (Hofman et al, 2009). Several studies related to decentralizations in Indonesian have been found in literature such as Lewis (2005 \& 2010). In addition, Pal and Wahhaj (2016) report a study on the impact of fiscal decentralization in Indonesia on local public spending across communities characterized by different types of informal and formal institutions. The results show new evidence that fiscal decentralization led to a significant increase in community spending on social infrastructure (health and education) in communities which observed strict adherence to customary laws and had a tradition of local democracy.

As a developing country, in order to improve it public service, the Government of Indonesia (GoI), after reformation era (after 1998), has been implementing decentralization by giving wide autonomy to the local government. Legally decentralization in Indonesia started by releasing UU No. 22 Year 1999 on Local Government. This law is revised by UU No. 32 Year 2004 and complemented by UU No. 12 Year 2008. It is stated that the objective of decentralization in Indonesia is to improve the public service and to shorten long path of bureaucracy which was the complaint from the community. In order to face the increasing global challenge, the local government must be equipped with a wide autonomy. Thus the wide local autonomy must be real, responsible, must be implemented proportionally in the local government.

In order to complete an effective public service that able to provide direct service to the community, in 2010 the Government of Indonesia has released a Ministry of Internal Affairs Regulation No 4 Year 2010 on manual of Integrated Administrative Service on District Area (in Bahasa shortened into PATEN). That regulation aimed to response the development of good governance in the local government. This is a very ambitious implementation of decentralization. The central government thinks that it needs to pay attention on the demands and requirements of community on services. By considering the geographic condition, the GoI want to optimize the role of district as a frontier of local government in providing public service for the community. By releasing the regulation No 4 Year 2010 means all of the integrated administrative service in districts in Indonesia must implement the regulation. It is mandatory in each district level of the government. As a note, the time limit for each district to implement the regulation is by year 2015. Even, in order to support and to accelerate the optimization the integrated administrative service in district level, the GoI released additional regulation, Kepmendagri No 138-270 Year 2010 on technical instruction on PATEN and recently in 2012, a Letter of Ministry of Home Affairs No138/113/PUM on acceleration implementation of PATEN has been released.

The above literature review shows that the study on decentralization in Asia, in particular in Indonesia has received big attention from researchers. However, to the best known of the author, study on the implementation of the decentralization in Indonesia to the district level of local government has not been found in the literature. Thus, the present study is focused on the implementation of Ministry of International Affairs Regulation No 4 Year 2010 where district level is expected as a frontier in delivering public services to the community. The objectives are to review the present implementation of PATEN, identify the barriers, and formulate suggestions. This is a case study with location of the study location is Medan city of Indonesia. The results are expected to support necessary 
information on development of good governance in order to make excellent public service into reality in Indonesia.

\section{METHOD}

\section{A. Design and Location of Research}

In the present study, the location of the research is Medan city. It is located in Sumatera Utara province and known as the third biggest city in Indonesia with a population of 2.21 million people. In Medan city, there are 21 districts, the name of district, area, population, and density are shown in Table 1 . In can be seen from the table that the most populated district is Medan Perjuangan and it is also the most densely district. Number of districts in Indonesia and in Sumatera Utara province is 6982 and 440 districts, respectively. As a note, the number of district in Indonesia is increasing due to autonomy, economy growth, and wideness.

Table 1 District of Medan city and its population in 2015 (Statistic Medan city, 2016)

\begin{tabular}{|c|c|c|c|c|}
\hline No & District & Area $\left(\mathrm{km}^{2}\right)$ & Population & $\begin{array}{c}\text { Density } \\
\text { (person/km²) }\end{array}$ \\
\hline 1 & Medan Tuntungan & 20.68 & 4,140 & 200 \\
\hline 2 & Medan Johor & 14.58 & 9,054 & 621 \\
\hline 3 & Medan Amplas & 11.19 & 11,068 & 989 \\
\hline 4 & Medan Denai & 9.05 & 16,139 & 1,783 \\
\hline 5 & Medan Area & 5.52 & 17,933 & 3,249 \\
\hline 6 & Medan Kota & 5.27 & 14,125 & 2,680 \\
\hline 7 & Medan Maimun & 2.98 & 13,645 & 4,579 \\
\hline 8 & Medan Polonia & 9.01 & 6,210 & 689 \\
\hline 9 & Medan Baru & 5.84 & 6,942 & 1,189 \\
\hline 10 & Medan Selayang & 12.81 & 8,286 & 647 \\
\hline 11 & Medan Sunggal & 15.44 & 7,499 & 486 \\
\hline 12 & Medan Helvetia & 13.16 & 11,453 & 870 \\
\hline 13 & Medan Petisah & 6.82 & 9,292 & 1,362 \\
\hline 14 & Medan Barat & 5.33 & 13,637 & 2,559 \\
\hline 15 & Medan Timur & 7.76 & 14,358 & 1,850 \\
\hline 16 & Medan Perjuangan & 4.09 & 23,443 & 5,732 \\
\hline 17 & Medan Tembung & 7.99 & 17,169 & 2,149 \\
\hline 18 & Medan Deli & 20.84 & 8,707 & 418 \\
\hline 19 & Medan Labuhan & 36.67 & 3,203 & 87 \\
\hline 20 & Medan Marelan & 23.82 & 6,812 & 286 \\
\hline 21 & Medan Belawan & 26.25 & 3,738 & 142 \\
\hline & Total & 265.10 & $2,210,624$ & 856 \\
\hline
\end{tabular}

Design of the present research is a combination of qualitative and quantitative approach with dominant-less model. There are several considerations for using this method. The first one is easily switched if double facts were found. The second is directly provides the relationship between researcher and respondent. The third reason is more responsive and able to adapt for many sharping influences and trends of facing values (Moelong, 2006). The collected data are analyzed by using descriptive-analytic method.

\section{B. Informant and Data Collection}

In order to collects the data several informants are used. They are head section of administrative and general governance of Medan city, head section of law of Medan city, two member of the city legislator, and all of 21 head district of Medan city. Thus a total of informants is used in this study. There are two type of data collection in here, the primary data and secondary data. The primary data are collected from the respondent directly by using questioner that contains closed and semi closed questions. In addition, Focus 
Group Discussions with all of the head regencies are carried out. The secondary data are collected by using third party sources such as document review, reports, publications, etc. Triangulation technique is employed to get the accurate information.

In order to collect the data from the community, number of the sample is calculated as suggested by Slovin (Sevilla et al, 1960 ) in the following equation.

$$
n=\frac{N}{1+N e^{2}}
$$

(1) where, $n$ is number of sample needed, $N$ is number of population, and $e$ is error tolerance. In the present work the error tolerance of 0.1 is used. As a note, number of population in Medan city is shown in Table 1. By using equation (1), the number of sample will be 99.99. Since, the number of district in Medan city is 21 districts, the number of population will be 5 people. Thus the total sample that will be used in this study is 105 people.

\section{Data Analysis}

In the qualitative approach, the analyses are carried out simultaneously with data collection, known as ongoing analysis. The qualitative analysis is done by following several processes such as data reduction, data presentation and the conclusion will be drawn based on the reduction and data presentation. In the quantitative approach, descriptive statistical analysis technique is used. The statistical analysis is used to analyze variables that are represented by frequency distributions such as in number and in percentage. The trends of the data will be analyzed.

\section{RESULTS AND DISCUSSIONS}

\section{A. Integrated Administrative Service on District Area (PATEN)}

The policy on integrated administrative service on district area is delivered in order to response the development of local government to become good governance system. Here the local government need to provide the needs and demand of the community in good services in the district level. The government of Medan want to implement ideas and new policy in the field of public services. As for the policy is based on thought how to make the services to the community besides able to do the default service standards, and also trying to how service locations get closer with the community so the service walk more quickly.

The idea could be realized by hold administration services integrated sub-district (a PATEN). Understanding PATEN is the public service in sub-district which the processes of funds, starting from entreaty up to the rising of documents done in one place .The PATEN not that it is a policy new because this policy is already in publishes since 2010 in the form of affairs regulation no 42010 .However until now the study is done, the government of the city of Medan not hold PATEN this. The unimplementation of PATEN this cause by several limitations owned by a government of the city of Medan which includes facilities and infrastructure, human resources, budget and commitment Medan city government.

By PATEN, it is hoped sub-district can serve the field of licensing and non licensing a small scale and that does not require technical study. PATEN held with a view to embody sub-district as a center of community service. Diversion of these services accompanied by this delegation of authority of a mayor to the related sub-district field.

According to affairs regulation no. 4/ 2010, sub-district as the PATEN must meet conditions contained, namely requirements substantive, requirements administrative and technical requirements. Requirements substantive as referred to in article 5 the minister of home no. 4 years 2010 was the delegation of part of their authority in the mayor/ district to the related sub-district. The delegation of part of their authority in covering: a field of licensing and field of non licensing. The delegation of the part of their authority to be set with mayor regulation. The delegation of part of their authority in the mayor/ the mayor also adopted by taking into account efficiency and effectiveness of service. It is meant to make the services that responsibility be by the mayor to the subdistrict right on target. 


\section{CONCLUSIONS AND RECOMMENDATIONS}

1. Leadership Obstacle

The main obstacles not success of PATEN policy in the city of Medan is because PATEN policy it is not exercised or non implementation policy. It means the government of the city of Medan did not implement a policy this PATEN, so that the impact of the implementation of the policy could not accomplished or be felt by the community of the city of Medan as the beneficiaries of the PATEN policy. Not implementation of PATEN policy in the city of Medan not because the policy not required by the city of Medan, but given the requirements and the ability sub-districts in the city of Medan. The government of the city of Medan had performed a study to rules interior minister no. 4/ 2010.

2. Policy Obstacle

PATEN was never realized because of PATEN policy unimplemented policy and poorly implemented policy .PATEN policy as unimplemented policy because implementor PATEN policy it does make a legal framework (in which the government of the city of Medan/ mayor not issued a regulation a mayor or perwal to accommodate the implementation of the PATEN by subdistrict) and the implementation arrangements, so that institutions that are supposed to be implementor the ground the sanctions (in this case sub-district) .

\section{The Effective Model of PATEN}

By PATEN, it is hoped sub-district can serve the field of licensing and non licensing a small scale and that does not require technical study. PATEN held with a view to embody Kecamatan as a center of community service. Diversion of these services accompanied by this delegation of authority of a mayor to the related sub-district field .In the implementation of a PATEN in 21 sub-districts in municipal Medan to be carried out more effective personnel in sub-district who action as a team technical implementation that is Sub-district Mayor and Sub-district Mayor Secretary and Head of Section on Sub-district.
The conclusions of the research is :

1. During this obstacles in the implementation of the PATEN is the absence of the delegation of authority from mayor on Kecamatan to implement PATEN, and central government through the interior ministry of had already made warning letter to of city government terrain for immediately turn PATEN in the region .

2. Of the city of Medan they had experienced no difficulty significant. But in the aspect of the quantity and quality of personnel in sub-district, of the city of Medan still should get organized because personnel current inadequate if later PATEN carried out.

3. A PATEN is the public service in the subdistrict the process of its management , ranging from the request came to document the rising done in one place .A model of the implementation PATEN effective in implementation in the city of Medan is the implementation of a PATEN for the field of licensing and field of non licensing with the term of the issuing a permit/ recommendations ranged between 1 (one) days for permission/ recommendations that does not require the field verification and 4 days for permission/ recommendations that requires the field verification. While resources that need to be taken includes: officers the ticket booths and equipment operators as well as supporting as computing and the internet network adequate.

The advises of this research is :

1. The government of Medan should to implement the delegation of authority to the Kecamatan which was formulated by a provincial regulation to immediately activated program PATEN because this is an urgent need to give better service on the community in Medan city.

2. The government of Medan city better do socialization an intense and touch every levels of society about the importance of licensing. It is important to increase the participation of the community as well as 
avoid the emergence of a pander offer services to the community lay.

3. The government of Medan city need to do strengthening both in the quality and quantity resources were deployed as security the PATEN good and sustainable.

\section{ACKNOWLEDGEMENT}

The authors gratefully acknowledge that the present research is supported by Ministry of Research and Technology and Higher Education Republic of Indonesia. The support is under the research grant TALENTA USU of Year 2016.

\section{REFERENCES}

Cain, P.M. (2014). Decentralization policy implementation to local government: A case study of good governance in management at municipality, Kalasin province, The Social Science 9(3), 217218.

Chattopadhyay, S. (2012). Decentralized urban governance: participation and accountability in West Bengal's municipalities. Environment and Urbanization Asia, 3(1), 185-202.

Cheema, S. G., \& Rondinelli, D. A. (2007). From government decentralization to decentralized governance. In Cheema, \& Rondinelli (Eds.), Decentralizing governance: Emerging concepts and practices. Washington: Brookings.

Clark, A. L., Fujiki, M. D., \& Davidson, M. (Eds.). (2008, August). The urban transformation in Asia: Policy implications of decentralization (EastWest Center summary report).

Faguet, J.-P. (2014). Decentralization and governance. World Development, 53, $2 \mathrm{e} 13$.

Hofman, B., Kaiser, K., \& Schulze, G. G. (2009). Corruption and decentralization. In C. J. G. Holzappel, \& M. Ramstedt (Eds.), Decentralization and regional autonomy in Indonesia (pp. 99-113). Singapore: Institute for Southeast Asian Studies.

Lewis, B. (2005). Indonesian local government spending, taxing and saving: An explanation of pre- and post- decentralization fiscal outcomes. Asian Economic Journal, 19(3), 291-317.

Lewis, B. (2010). Indonesian decentralization: Accountability deferred, International Journal of Public Administration, 33(12), 648-657.

McLeod, R. (2005). The struggle to regain effective government under democracy in Indonesia. Bulletin of Indonesian Economic Studies, 41(3), 367-386.

Pal S., Wahhaj, Z. (2016). Fiscal decentralization, local institutions and public good provision: evidence from Indonesia, Journal of Comparative Economics 000, 1-27.

Rainer Rohdewohld. (1995). Public administration in Indonesia, Monash University.

Rumbach, A. (2016). Decentralization and small cities: Towards more effective urban disaster governance? Habitat International 52, 35-42.

Rochyati. (2012). Mengenal Implementasi Kebijakan Publik, Surabaya: Universitas Airlangga

Sevilla, Consuelo et, Al. (1993). Pengantar Metode Penelitian. Jakarta : Universitas Indonesia Press.

Sjahrir B.S., Kis-Katos, K., Sculze, G.G. (2016). Administrative over spending in Indonesia Districts: the role of local politics, World Development, 59, 166183.

Sumaryadi, I Nyoman. (2005). Efektivitas Implementasi Kebijkan Otonomi Daerah. Jakarta : Citra Utama 